DOI: 10.12731/2658-6649-2019-11-5-54-57

УДК 616.831

\title{
АНАЛИЗ СЕРОЛОГИЧЕСКИХ ИССЛЕДОВАНИЙ СЫВОРОТОК КРОВИ НА КЛЕЩЕВОЙ ЭНЦЕФАЛИТ У НАСЕЛЕНИЯ ТЮМЕНСКОЙ ОБЛАСТИ ЗА 2016-2018 ГОДА
}

Зацепина А.О., Леонтьева С.А., Брагина Е.А.

Представлены результаты серологических исследований сывороток крови людей на содержание иммуноглобулина класса $M$ к вирусу клещевого энцефалита у жителей г. Тюмени и юга Тюменской областиза 2016-2018 г2.

Ключевые слова: клещевой энщефалит; иммуноглобулин.

\section{ANALYSIS OF INFECTION \\ BY TICK ENCEPHALITIS IN THE POPULATION OF THE TYUMEN REGION IN 2016-2018}

\section{Zatsepina A.O., Leonteva S.A., Bragina E.A.}

The results of serological studies of blood sera of people on the content of class $M$ immunoglobulin to tick-borne encephalitis virus in residents of the south of the Tyumen region for 2016-2018 are presented.

Keywords: tick-borne encephalitis; immunoglobulin.

\section{Введение}

Клещевой энцефалит (КЭ) - это инфекция центральной нервной системы, вызываемая вирусом клещевого энцефалита, передаваемым человеку преимущественно трансмиссивным путем. Наиболее важную роль в эпидемиологическом плане играют иксодовые клещи, которые повсеместно распространенны на всей территории области. Вся территория Тюменской области является эндемичной по заболеваемости клещевым вирусным энцефалитом. Ареал природного очага охватывает 23 административные территории. Климатические и ландшафтно-географические 
факторы создают на территории области благоприятные условия для формирования и существования природных очагов клещевого энцефалита. В течение последних десятилетий заболеваемость увеличивалась и создала проблему со здоровьем почти во всех эндемичных странах Европы и Азии [1, с. 15].

\section{Цель работы}

Выявить процент серопозитивности иммуноглобулина класса $\operatorname{lgM}$ к вирусу клещевого энцефалита в сыворотке крови у жителей Тюменской области за 2016-2018 гг.

\section{Материалы и методы исследования}

Материал поступал в течение года в лабораторию трансмиссивных вирусных инфекций ФБУН ТНИИКИП Роспотребнадзора от населения Тюменской области с клиническими проявлениями заболевания. Исследование проводили методом иммуноферментного анализа, у людей определяли наличие специфических антител класса $\lg$ к в вирусу КЭ, наборами «ВектоВКЭ-lgМ», производство ЗАО Вектор-Бест, г. Новосибирск. Анализировали сыворотки с положительным уровнем $\operatorname{lgM}$, так как синтез антител к вирусным агентам начинается с выработки антител класса М и говорит об «остром начале» заболевания.

\section{Результаты и обсуждения}

Было исследовано 388 сывороток крови людей за 2016 г., 452 2017 г., 277-2018 г., проживающих на территории области (гг. Заводоуковск, Ишим, Тобольск, Тюмень, Ялуторовск). Наибольший процент сероположительных реакций к КЭ (острое течение заболевания, которое определяли по титру иммуноглобулина класса М) наблюдался в 2016 году в весенний период в г. Ишиме - 50,0 $25,0 \%$, наименьший в г. Тюмени $-4,9 \pm 2,1 \%$. В летний период этого же года процент обратившихся в клинику института в г. Тюмени имел тенденцию к повышению и составил $6,6 \pm 2,5 \%$. Осенью этого года среди жителей г. Заводоуковска выявлено максимальное число серопозитивных сывороток к $\lg \mathrm{M}-$ $100 \%$; в г. Ишиме $-16,7 \pm 15,2 \%$; в г. Тюмени $-8,2 \pm 3,2 \%$. В 2017 году процент выявленных положительных проб в весенний период из г. Тюмени составил $6,0 \pm 2,1 \%$; летом наибольший процент: г. Тобольск $20,0 \pm 17,8 \%$, г. Ишим - $16,6 \pm 15,1 \%$. В г. Тюмени за летний и осенний периоды наблюдалась стабильная динамика, процент положитель- 


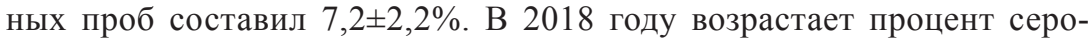
положительных реакций. В весенний период в г. Тюмени $-8,6 \pm 4,7$; в летний период в г. Ишиме - 38,5 $\pm 13,4 \%$, г. Тобольске $-33,3 \pm 27,2 \%$, г. Заводоуковске $-25,0 \pm 15,3 \%$, что показывает увеличение процента серопозитивных проб сывороток крови по сравнению с предыдущим годом; в осенний период динамика остается прежней. В г.Тюмени процент положительных проб в 2018 году в летний период составил $-6,6 \pm 2,8 \%$, в осенний $-8,5 \pm 3,6 \%$. За рассматриваемые периоды времени положительных проб среди жителей из г. Ялуторовска не было выявлено.

По результатам исследований, в г.Тюмени наблюдаются самые низкие и стабильные проценты выявления титров иммуноглобулина класса М к вирусу клещевого энцефалита по сравнению с другими городами Тюменской области.Одна их возможных причин, это постоянная акарицидная обработка территории города. Тогда как в других городах Тюменской области прослеживается не стабильная динамика. Возможно, это является следствием плохой осведомленностью населения, не соблюдения неспецифической индивидуальной защиты и не проведением своевременных мероприятий по акарицидной обработки.

\section{Список литературы / References}

1. Süss J. Tick-borne encephalitis 2010: epidemiology, risk areas, and virus strains in Europe and Asia-an overview. TicksTickBorneDis. 2011; №2, pp. 2-15.

\section{ДАННЫЕ ОБ АВТОРАХ}

Зацепина А.O., м.н.с

ФБУН Тюменский научно исследовательский институт краевой инфекиионной патологии Роспотребнадзора

ул. Республики, 147, г. Тюмень, 625026, Российская Федерация

Леонтьева С.А., Н.с.

ФБУН Тюменский научно исследовательский институт краевой инфекиионной патологии Роспотребнадзора

ул. Республики, 147, г. Тюмень, 625026, Российская Федерация

Брагина Е.А., в.н.c.

ФБУН Тюменский научно исследовательский институт краевой инфекиионной патологии Роспотребнадзора

ул. Республики, 147, г. Тюмень, 625026, Российская Федерачия 
DATA ABOUT THE AUTHORS

Zatsepina A.O., scientific researcher

Tyumen Region Infection Pathology Research Institute

147, Respubliki Str., Tyumen, 625026, Russian Federation

Leontyeva S.A., scientific researcher

Tyumen Region Infection Pathology Research Institute

147, Respubliki Str., Tyumen, 625026, Russian Federation

Bragina E.A., scientific researcher

Tyumen Region Infection Pathology Research Institute

147, Respubliki Str., Tyumen, 625026, Russian Federation 